\title{
Studi Eksperimental Penambahan Serbuk Arang Kayu Dengan Kadar 10\% Terhadap Filler Semen Pada Campuran Perkerasan AC - WC
}

\author{
Kurnia Hadi Putra ${ }^{1}$, Mutiara Fidausi ${ }^{2}$ \\ Jurusan Teknik Sipil - FTSP - ITATS ${ }^{1}$, Jurusan Teknik Sipil - FTSP - ITATS ${ }^{2}$ \\ Email: kurnia_putra@itats.ac.id
}

\begin{abstract}
ABSTRAK: Jenis lapis perkerasan aspal yang sifatnya struktural dan umum dipakai di Indonesia adalah Lapis Aspal Beton (Laston) dengan lapis aus atau lapis permukaan (Wearing Course). Lapisan tersebut merupakan lapisan yang paling rentan dengan kerusakan yang diakibatkan oleh repitisi beban kendaraan dan cuaca. Penelitian ini mecoba serbuk arang kayu dapat dimanfaatkan sebagai filler dalam campuran aspal sebagai alternatif pengganti semen. Dalam penelitian ini pembuatan benda uji mengacu pada Spesifikasi Bina Marga 2010 (Divisi VI). Digunakan variasi serbuk arang kayu 10\%. Dari data Marshall Test yang didapatkan, memenuhi persyaratan sesuai Spesifikasi Bina Marga 2010 adalah serbuk arang kayu yang berkadar 10\%. Pada benda uji serbuk arang kayu 10\% dihasilkan VIM sebesar 5,32 \%, VMA sebesar 17,81, Void Filled sebesar 70,18, stabilitas sebesar 1354, Flow sebesar 3,17, Marshall Quetiont sebesar 427,5 , tebal selimut aspal sebesar 8,020. Sehingga dapat di simpulkan bahwa kandungan variasi serbuk arang kayu $10 \%$ meningkatkan nilai Marshall Test.
\end{abstract}

Kata Kunci : Filler, Serbuk arang kayu, Lapisan aspal beton AC-WC, Uji Marshall.

\section{LATAR BELAKANG}

Jalan raya merupakan salah satu prasarana perhubungan darat yang mempunyai peranan penting bagi pertumbuhan perekonomian, sosial budaya, pengembangan wilayah pariwisata, dan pertahanan keamanan untuk menunjang pembangunan nasional. [1]

Perkembangan masyarakat telah berdampak kepada semakin banyaknya permintaan akan jasa transportasi jalan raya. Tingginya permintaan terhadap jasa transportasi jalan raya tidak hanya ditandai dengan meningkatnya volume lalu lintas kendaraan tetapi juga dengan tekanan beban kendaraan yang tinggi sehingga struktur lapis perkerasan jalan beraspal dituntut untuk dapat melayani dengan baik perubahan-perubahan tersebut. Sementara di sisi lain faktor cuaca dan suhu juga sangat mempengaruhi keawetan lapis permukaan aspal. [2]

Semakin banyaknya tingkat kecelakaan lalu lintas di Indonesia. Kecelakaan lalu lintas merupakan masalah yang membutuhkan penanganan serius mengingat besarnya kerugian yang diakibatkannya. Salah satu faktor dalam kecelakaan di jalan raya adalah kerusakan suatu jalan tersebut. Adapun salah satu contohnya yaitu genangan air di permukaan pekerasan jalan. Tergenangnya air di permukaan jalan raya yang disebabkan oleh air hujan dapat membahayakan pengguna jalan raya, sehingga keselamatan mereka terancam kejadian kecelakaan. Maka dari itu, untuk menjaga keselamatan para pengguna jalan perlu perencanaan struktur perkerasan jalan yang baik. [2]

Salah satu jenis Lapis perkerasan aspal yang sifatnya struktural dan umum dipakai di Indonesia adalah Lapis Aspal Beton (Laston) dengan lapis aus atau lapis permukaan (Wearing Course). Lapisan tersebut merupakan lapisan yang paling rentan dengan kerusakan yang diakibatkan oleh repitisi beban kendaraan dan cuaca. Telah banyak dilakukan berbagai penelitian tentang pencampuran bahan aditif (bahan tambah) dengan campuran perkerasan Laston-WC yang bertujuan meningkatkan stabilitas aspal. Berdasarkan hal tersebut, dilakukan penelitian penambahan serbuk arang kayu ke dalam aspal yang bertujuan meningkatkan titik lembek aspal, memperkecil nilai penetrasi aspal dan memperkecil presentase kehilangan berat aspal akibat pemanasan. [3]

Salah satu jenis Lapis perkerasan aspal yang sifatnya struktural dan umum dipakai di Indonesia adalah Lapis Aspal Beton (Laston) dengan lapis aus atau lapis permukaan (Wearing Course). Lapisan tersebut merupakan lapisan yang paling rentan dengan kerusakan yang diakibatkan oleh repitisi beban kendaraan dan cuaca. Telah banyak dilakukan berbagai penelitian tentang pencampuran bahan aditif (bahan tambah) dengan campuran perkerasan Laston-WC yang bertujuan meningkatkan stabilitas aspal. Berdasarkan hal tersebut, dilakukan penelitian penambahan serbuk arang kayu ke dalam aspal yang bertujuan meningkatkan titik lembek aspal, memperkecil nilai penetrasi aspal dan memperkecil presentase kehilangan berat aspal akibat pemanasan. [3]

Arang kayu (Wood Charcoal) adalah residu yang mengandung karbon yang dihasilkan dengan cara dibakar dengan pemanasan pada suhu tinggi dengan bahan dasar kayu. Arang berwarna hitam, berbobot ringan, $80 \%$ komposisinya berupa karbon. Arang ini terdiri 85\% sampai $98 \%$ karbon, sisanya adalah abu atau benda kimia lainnya. Melihat kondisi arang kayu yang mengandung karbon aktif tersebut, diharapkan pecampuran arang kayu kedalam aspal dapat meningkatkan kinerja dari pekerasan Laston-WC seperti nilai daktilitas, menahan penguapan ketika dipanaskan (menaikkan titik nyala) dan sifat-sifat dasar aspal lainnya. [4] 


\section{METODE PENELITIAN}

\section{Pengujian Aspal Pen 60/70}

Pemeriksaan sifat aspal pen 60/70 dari campuran perkerasan Laston-WC dilakukan melalui beberapa uji meliputi:

1. Uji penetrasi

2. Titik Lembek

3. Berat Jenis

4. Titik Nyala dan Titik Bakar

5. Kelekatan Aspal pada Agregat

\section{Uji penetrasi}

Percobaan ini bertujuan untuk mentukan apakah aspal keras atau lembek (solid atau semi solid) dengan memasukkan jarum penetrasi ukuran tertentu, beban, waktu tertentu kedalam aspal pada suhu tertentu. Pengujian ini dilakukan dengan membebani permukaan aspal seberat 100 gram pada tumpuan jarum berdiameter $1 \mathrm{~mm}$ selam 5 detik pada temperatur $25^{\circ} \mathrm{c}$.

\section{Titik Lembek}

Titik lembek adalah temperature pada saat bola baja dengan berat tertentu mendesak turun suatu lapisan aspal yang tertahan dalam cincin berukuran tertentu, sehingga aspal tersebut menyentuh plat dasar yang terletak di bawah cincin pada tinggi tertentu sebagai akibat kecepatan pemanasan tertentu.

\section{Daktalitas}

Pengujian daktalitas ini bertujuan untuk mengetahui sifat kohesi dari aspal, dengan mengukur jarak terpanjang yang dapat di tarik antara dua cetakan yang berisi aspal keras sebelum putus, pada suhu dan kecepatan tertentu.

\section{Berat Jenis}

Pengujian ini bertujuan untuk menentukan berat jenis aspal keras dengan alat piknometer. Berat jenis aspal adalah perbandingan antar berat aspal dan berat zat cair suling dengan volume yang sama pada suhu $25^{\circ} \mathrm{c}$.

\section{Pengujian Agregat}

Pemilihan agregat yang tepat dan memenuhi persyaratan akan sangat menetukan daya dukung perkerasan dan keberhasilan pembangunan atau pemeliharaan jalan. Pada campuran beraspal, agregat memberikan kontribusi sampai 90\%-95\% terhadap berat campuran, sehingga sifat-sifat agregat merupakan salah satu faktor penentu dari kinerja campuran tersebut.

1. Sifat agregat yang harus diperiksa antara lain:

2. Ukuran butir

3. Gradasi

4. Kebersihan

5. Kekerasan

6. Bentuk partikel

7. Tekstur permukaan

8. Penyerapan

9. Kelekatan terhadap aspal

Berat jenis suatu agregat adalah perbandingan berat dari suatu satuan volume bahan terhadap berat air dengan volume yang sama pada temperature $20^{\circ} \mathrm{C}-25^{\circ} \mathrm{C}\left(68^{\circ} \mathrm{F}\right.$ $77^{\circ} \mathrm{F}$ ). beberapa macam berat jenis agregat:
- Berat jenis semu (apparent specific gravity), Berat jenis semu, volume dipandang sebagi volume pori yang dapat terisi air setelah perendaman selam 24 jam.

- Berat jenis bulk (bulk specific gravity), Berat jenis bulk, volume dipandang volume menyeluruh agregat termasuk volume pori yang dapat terisi oleh air setelah direndam selama 24 jam.

- Berat jenis efektif, Berat jenis efektif, volume dipandang volume menyeluruh dari agregat tidak termasuk volume pori yang dapat menghisap aspal.

\section{Pengujian Marshall}

Pada percobaan ini menggunakan benda uji standar berupa sebuah cetakan yang berdiameter 101,6 mm (4 inci) dan tinggi $75 \mathrm{~mm}$ (3 inci). Benda uji didapatkan dengan menggunakan alat pemadat Marshall (Marshall Compaction Hummer) dengan berat 4,54 kg (10 lbs), diameter 3. 7/8 inci dan tinggi jatuh $457 \mathrm{~mm}$ (18 inci). Hasil uji akan menunjukkan karakteristik Marshall dan karakteristik akan dipengaruhi oleh sifat-sifat campuran yaitu: Kepadatan, Rongga mineral diantara Agergat (VMA), Rongga terisi aspal (VFA), Rongga udara dalam campuran (VIM), Nilai stabilitas dan Pelelehan.

\section{HASIL PENELITIAN Pengujian Aspal}

Dalam penelitian ini, aspal yang digunakan adalah aspal Pertamina dengan penetrasi 60/70.

Tabel 1. Hasil Pengujian Sifat Fisik Aspal Penetrasi $60 / 70$

\begin{tabular}{|c|c|c|c|c|c|c|}
\hline \multirow[t]{2}{*}{ No } & \multirow{2}{*}{$\begin{array}{c}\text { Jenis } \\
\text { Pemeriksaa } \\
\mathrm{n}\end{array}$} & \multirow[t]{2}{*}{ Unit } & \multirow[t]{2}{*}{ Metode Uji } & \multicolumn{2}{|c|}{ Spesifikasi } & \multirow{2}{*}{$\begin{array}{c}\text { Hasil } \\
\text { pemeriks } \\
\text { aan }\end{array}$} \\
\hline & & & & Min & Max & \\
\hline 1 & $\begin{array}{l}\text { Penetrasi } \\
25^{\circ} \mathrm{c}, 100 \mathrm{gr} \text {, } \\
5 \text { detik }\end{array}$ & $\mathrm{mm}$ & $\begin{array}{l}\text { SNI 06- } \\
\text { 2456-1991 }\end{array}$ & 60 & 70 & 70 \\
\hline 2 & $\begin{array}{l}\text { Titik } \\
\text { Lembek } 5^{\circ} \mathrm{c}\end{array}$ & ${ }^{\circ} \mathrm{C}$ & $\begin{array}{l}\text { SNI 2434- } \\
2011\end{array}$ & 48 & - & 49 \\
\hline 3 & Titik Nyala & ${ }^{\circ} \mathrm{C}$ & $\begin{array}{l}\text { SNI 2433- } \\
2011\end{array}$ & 232 & - & 312 \\
\hline 4 & $\begin{array}{l}\text { Kehilangan } \\
\text { Berat } \\
\text { (dengan } \\
\text { TFOT) }\end{array}$ & $\%$ & $\begin{array}{l}\text { SNI 06- } \\
2441-1991\end{array}$ & - & 0,8 & 0.2073 \\
\hline 5 & $\begin{array}{l}\text { Kelarutan } \\
\text { aspal dalam } \\
\text { C2HCL3 }\end{array}$ & $\%$ & $\begin{array}{l}\text { AASHTO } \\
\text { T44-03 }\end{array}$ & 99 & - & 99.713 \\
\hline 6 & Berat jenis & $\begin{array}{l}\mathrm{gr} / \mathrm{c} \\
\mathrm{c}\end{array}$ & $\begin{array}{l}\text { SNI 2441- } \\
2011\end{array}$ & 1 & - & 1.032 \\
\hline
\end{tabular}

\section{Pemeriksaan Penetrasi Aspal}

Pengujian ini didasarkan pada SNI 06-2456-1991. Dari hasil pengujian, didapatkan nilai penetrasi 70 yang menunjukkan termasuk aspal penetrasi 60/70. Nilai penetrasi ini memenuhi Spesifikasi Departemen 
Pekerjaan Umum tahun 2010 Revisi III yaitu nilai penetrasi aspal pada rentang 60-70.

\section{Pemeriksaan Titik Lembek}

Pengujian ini didasarkan pada SNI 2434-2011. Nilai yang didapatkan dari hasil pemeriksaan titik lembek aspal sebesar $49^{\circ} \mathrm{c}$. Nilai ini telah memenuhi Spesifikasi Departemen Pekerjaan Umum Tahun 2010 Revisi III yang telah menetapkan persyaratan titik lembek minimal $48^{\circ} \mathrm{c}$.

\section{Pemeriksaan Titik Nyala}

Pengujian ini didasarkan pada SNI 2433-2011. Dari hasil pemeriksaan aspal penetrasi 60/70 titik bakarnya adalah sebesar $312^{\circ} \mathrm{c}$ dan nilai titik nyal yaitu $232^{\circ} \mathrm{c}$ ini telah memenuhi dalam Spesifikasi Departemen Pekerjaan Umum Tahun 2010 Revisi III.

\section{Pemeriksaan Kehilangan Berat}

Pengujian ini didasarkan pada SNI 06-2441-1991. Pada pemeriksaan ini kehilangan berat ini menggunakan sampel yang sama untuk penetrasi, yaitu setelah aspal dilakukan TFOT. Hasil pemeriksaan kehilangan berat ini menunjukkan aspal kehilangan berat sebesar 0,2073. Hasil ini sama seperti Spesifikasi Departemen Pekerjaan Umum Tahun 2010 Revisi III yang menetapkan persyaratan maksimal sebesar $0,4 \%$.

\section{Pemeriksaan Kelarutan Aspal Dalam Karbon} Tetraklorida (C2HCL3)

Di dalam pengujian ini didasarkan pada SNI 06-24381991. Nilai pemeriksaan kelarutan menujukkan kemurnian aspal dan normalnya bebas dari air. Pengujian ini ini didasarkan pada nilai kelarutan C2HCL3 adalah sebesar $99.713 \%$, yang masih memenuhi Spesifikasi Departemen Pekerjaan Umum Tahun 2010 Revisi III yang menetapkan persyaratan minimalnya sebesar $99 \%$.

\section{Pemeriksaan Berat Jenis Aspal}

Didalam pengujian ini didasarkan pada SNI 2441-2011. Dari hasil pengujian ini didapatkan berat jenis aspla sebesar $1.0228 \mathrm{gr} / \mathrm{cc}$, dimana hasil ini telah memenuhi Spesifikasi Departemen Pekerjaan Umum Tahun 2010 Revisi III yang menetapkan batas minimum berat jenis aspal sebesar $1 \mathrm{gr} / \mathrm{cc}$.

\section{Pengujian Agregat}

Untuk mengetahui sifat-sifat atau karakteristik agregat, pada penelitian ini pengujian agregat yang dilakukan dari Coarse Aggregate, Medium Aggregate, Fine Aggregate serta Stone Dust. Pengujian ini dilakukan didasarkan pada Standart Nasional Indonesia (SNI). Gradasi yang ditinjau didasarkan pada gradasi laston lapis permukaan (AC-WC) dari Spesifikasi Departemen PU Tahun 2010.

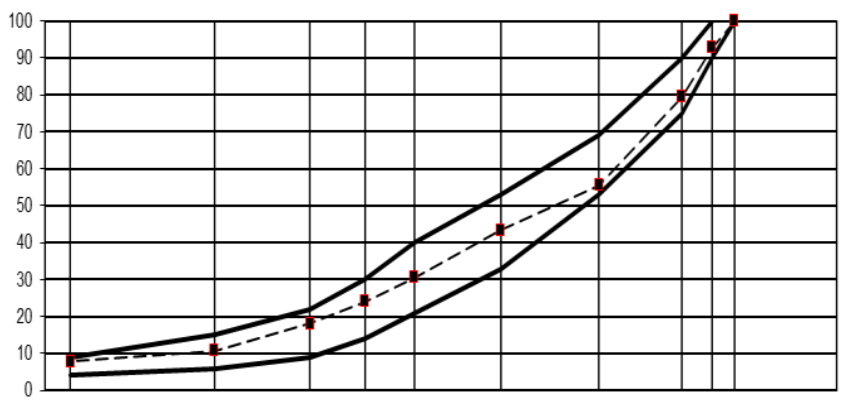

Gambar 1. Kombinasi Gradasi Agregat
Tabel 2. Pengujian Berat Jenis

\begin{tabular}{|c|l|c|c|c|c|}
\hline No. & Agregat & Berat Jenis & $\begin{array}{c}\text { Berat } \\
\text { Jenuh }\end{array}$ & $\begin{array}{l}\text { Berat } \\
\text { Kering }\end{array}$ & Penyerapan \\
\hline 1 & Agregat halus & 2.565 & 2.611 & 2.691 & 1.829 \\
\hline 2 & Agregat sedang & 2.575 & 2.625 & 2.711 & 1.943 \\
\hline 3 & Agregat Kasar & 2.694 & 0.915 & 2.823 & 1.002 \\
\hline 4 & Filler & 3.150 & & 3.150 & \\
\hline
\end{tabular}

\section{Komposisi Dan Proporsi Benda Uji Marshall}

Komposisi dan penentuan proporsi agregat dibuat dari data-data hasil analisis butiran masing-masing agregat yang tertahan di masing-masing saringan. Jenis campuran yang digunakan adalah gradasi kasar yang sesuai dengan peruntukan campuran AC-WC berdasarkan Spesifikasi Departemen Pekerjaan Umum tahun 2010. Pada penelitian ini, bahwa jumlah sampel yang dibutuhkan untuk mencari kadar aspal ideal sebanyak 9 buah dengan variasi kadar aspal 4\%, 5\%, 6\%. Sampel benda uji dibuat dengan metode Marshall.

\section{Komposisi Dan Proporsi Benda Uji Marshall}

Komposisi dan penentuan proporsi agregat dibuat dari data-data hasil analisis butiran masing-masing agregat yang tertahan di masing-masing saringan. Jenis campuran yang digunakan adalah gradasi kasar yang sesuai dengan peruntukan campuran AC-WC berdasarkan Spesifikasi Departemen Pekerjaan Umum tahun 2010. Pada penelitian ini, bahwa jumlah sampel yang dibutuhkan untuk mencari kadar aspal ideal sebanyak 9 buah dengan variasi kadar aspal 4\%, 5\%,6\%. Sampel benda uji dibuat dengan metode Marshall.

\section{KESIMPULAN}

Kesimpulan dalam penelitian ini, dapat dilihat pengaruh dalam penggunan variasi serbuk arang kayu $10 \%$ sebagai bahan tambah campuran perkerasan AC-WC adalah dengan penambahan kadar seruk arang kayu $10 \%$ terhadap filler semen dapat meningkatkan nilai Marshall Test. Dari data Marshall Test. Didapatkan data berdasarkan analisis kadar filler serbuk arang kayu sebesar 10\% diperoleh nilai stabilitas sebesar $1354 \mathrm{~kg}$, nilai flow sebesar 3,17 mm, Marshall Quetiont sebesar $427,50 \mathrm{~kg} / \mathrm{mm}$, VIM sebesar 4.34\%, VMA sebesar 17.81 $\%$, Void filled sebesar 70,18\%.

\section{DAFTAR PUSTAKA}

[1] Sukirman, Silvia;. (2010). Perencana Tebal Struktur Perkerasan Lentur. Bandung: Nova. 
[2] Permana, Shezy Nurhayati; Prasetyanto, Dwi; Zurni, Rahmi;. (n.d.). Studi Penggunaan Limbah Las Karbit Untuk Bahan Tambah Pada Perkerasan Laston $A C$ - $W C$.

[3] Hendarsin, L Shirley (2000), Perencanaan Teknik Jalan Raya. Politeknik Negeri Bandung

[4] Polii, Fahri Ferdinand; (2017). Pengaruh Suhu Dan Lama Aktifasi Terhadap Mutu Arang Aktif Dari Kayu Kelapa. Balai Riset Dan Standarisasi Manado.

[5] Badan Standarisasi Nasional, 1991, SNI 062433-1991, Cara Uji Titik Nyala Dan Titik Bakar Aspal Dengan Alat Cleveland Open Cup. Departemen Pekerjaan Umum, Badan Penelitian dan Pengembangan Departemen Pekerjaan Umum.

[6] Bina Marga Direktorat Jendaral, Spesifikasi Umum tahun 2010 Revisi III. Departemen Pekerjaan Umum. Jakarta

[7] Badan Standarisasi Nasional, 2008, SNI 2417:2008, Cara Uji Keausan Agregat Dengan Mesin Abrasi Los Angeles, Departemen Pekerjaan Umum, Badan Penelitian dan Pengembangan Departemen Pekerjaan Umum.

[8] Badan Standarisasi Nasional, 1991, SNI 062441-1991, Cara Uji Berat Jenis Aspal Keras, Departemen Pekerjaan Umum, Badan Penelitian dan Pengembangan Departemen Pekerjaan Umum.

[9] Badan Standarisasi Nasional, 1991, SNI 062456-1991, Cara Uji Penetrasi Aspal, Departemen Pekerjaan Umum, Badan Penelitian dan Pengembangan Departemen Pekerjaan Umum.

[10] RSNI M-01-2003;. Metode Pengujian Campuran Beraspal Panas Dengan Alat Marshall. Badan Standardisasi Nasional.

[11] Kementerian Pekerjaan Umum Dan Perumahan Rakyat;(2017). Manual Perkerasan Jalan. Jakarta: Direktorat Jenderal Bina Marga.

[12] Departemen Pekerjaan Umum: 2002. Pedoman Perkerasan Lentur Metode Bina Marga (Pt T-01-2002-B), Jakarta. 